Journal Home Page:

http://perlinguam.journals.ac.za

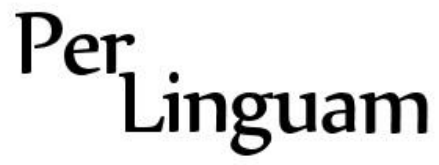

A Journal for Language Learning Tydskrif vir Taalaanleer

\title{
POLICY, PRACTICE, PURPOSE: THE TEXT-BASED APPROACH IN CONTEMPORARY SOUTH AFRICAN EFAL CLASSROOMS
}

Ntombi Mohlabi-Tlaka, University of South Africa

Lizette J. de Jager, University of Pretoria

Alta Engelbrecht, University of Pretoria

Curriculum implementation ought to be considered the main driving force for achieving the envisaged teaching and learning objectives. However, a major gap seems to exist between curriculum stipulations and actual classroom practice in many disadvantaged South African public schools. The CAPS prescribes both text-based and communicative approaches for English FAL and provides a description of the text-based approach, including several teaching guidelines. The authors believe that this form of prescriptiveness is advantageous as similar operational standards are given across the board. This article presents an account of a doctoral study that explored text-based teaching for communicative competence in Grade 4 in three public schools that offer English to learners whose mother tongue is not English. The study, which adhered to research ethical standards, intended to narrow the existing gap by interrogating curriculum knowledge and practice of the prescribed EFAL approach within a specific context. While the research did not intend to investigate the departmental language intervention strategy implemented during the period, empirical evidence revealed that the execution of the text-based approach was fundamentally influenced by the strategy. Whereas the participants acclaimed the text-based approach, they had limited knowledge and understanding of curriculum matters and the prescribed approach. Due to contextual limitations, the results were not to be generalised. Recommendations for future research on policy development and implementation were put forward.

Keywords: Curriculum and Assessment Policy Statement; communicative competence; First Additional Language; objective; teaching practice; text-based approach

\section{INTRODUCTION}

The purpose of this article is to give an account of part of a doctoral study that was completed in August 2016. The research sought to explore the text-based approach and its contribution to English FAL teaching for the development of learners' communicative competence in Grade 4. The entire thesis could not be accommodated, hence the presentation of a selected part of the research.

By means of purposive non-probability sampling, three participants from disadvantaged public schools were selected from a target population of teachers who represented a 'group of individuals with some common defining characteristics that the researcher can identify and study' (Creswell, 2012: 142). To protect the participants and to uphold the researcher's integrity, ethical standards were observed. 
The text-based approach is prescribed in conjunction with the communicative approach in the Curriculum and Assessment Policy Statement (CAPS) for First Additional Language (FAL) teaching and learning in the Intermediate Phase, and is aimed at developing competent speakers, readers, writers and viewers of texts (Department of Basic Education (DBE), 2011: 18).

In South Africa, English is the FAL in public schools that cater for learners who do not have English as home language. In reality, learners in many of these schools are introduced to English in Grade 3 or Grade 4. Grade 4 is the entry level into the intermediate phase - a critical transitional developmental stage because, at this stage, learners are expected to have learnt to read 'and are now reading to learn' (Mullis, Martin, Foy \& Drucker, 2012: 25). Moreover, the stage is critical since learners at these schools have to start using the FAL as a language of learning and teaching (LoLT). However, many learners struggle to read and consequently progress without the requisite skills 'that are supposed to be well developed by the end of Grade 3' (Pretorius, 2012: 92).

\section{BACKGROUND}

Numerous studies have shown that many learners find it difficult to use English as a second language (Jordaan, 2011; Pretorius, 2012; Schlebush \& Motsamai, 2004; Seligmann, 2011) and that many learners' reading and writing skills are at levels much lower than expected standards (McCabe, 2013; Mouton, Louw \& Strydom, 2013; National Education Evaluation and Development Unit, 2012). This language deficiency becomes a challenge that affects learners' academic performance, leading to poor performance in higher education (Ayliff, 2010; Van Schalkwyk, 2008).

The situation, as depicted, has mainly been attributed to inadequate capacities and lack of high levels of knowledge and teaching skills on the teachers' part (DBE, 2013; Hoadley, 2010; Spaull, 2013). Killen (2015: 1) advises that to 'function effectively as a teacher in South Africa you need to be able to interpret and follow the guidelines given in the National Curriculum Statement Grades R-12'. Teaching knowledge, teaching skills and curriculum interpretation are areas referred to as pedagogical content knowledge, which embraces the kinds of knowledge required for successful delivery of the curriculum and effective classroom teaching, thereby putting the language policy into practice for the fulfilment of the envisaged curriculum goals. These kinds of knowledge are distinguished into essential categories, described as 'subject content knowledge, pedagogical content knowledge and curriculum knowledge’ (Shulman, 1986: 9).

In this article, we purport that communicative competence (Hymes, 1966, 1972) should be given prominence as an essential outcome in FAL teaching and learning. Richards (2006: 3) explains that communicative competence includes 'knowing how to use language for a range of different purposes and functions; knowing how to vary our use of language according to the setting and participants; knowing how to produce and understand different types of texts' and 'knowing how to maintain communication despite having limitations in one's language knowledge'. Consequently, by means of appropriate teaching practice, the four aspects of communicative competence could be achieved at appropriate levels. It is therefore critical for teachers to be familiar with the concept and to be equipped with pedagogical intervention skills to develop learners' communicative competence in the FAL. In principle, the main argument put forward is that, if language is the tool for both oral and written communication (DBE, 2011), 
communicative competence should be prioritised and clearly articulated in the policy statement as a specific outcome in first additional language teaching.

\section{PROBLEM STATEMENT}

Teachers' inability to deliver the curriculum results in poor teaching and learning standards, leading to failure in achieving the requisite curriculum objectives. The problem is that teachers are not fully conversant with curriculum matters and, whereas teaching takes place on a daily basis, learners continuously battle to acquire essential language proficiency skills (Nel \& Theron, 2008; Van Staden, 2011). The fact that, at this level, learners are expected to begin learning all content subjects in the medium of English exacerbates the state of affairs.

Against this backdrop, the following questions were formulated to establish how the text-based approach to English FAL was understood and practised, and how it contributed to the development of learners' communicative competence at Grade 4 level:

- How is the text-based approach to teaching English implemented in Grade 4 to ensure communicative competence?

- What is the teachers' understanding of the text-based approach?

\section{IMPLEMENTING THE TEXT-BASED APPROACH}

The DBE (2011: 8) English FAL curriculum explains the text-based approach as follows:

A text-based approach explores how texts work. The purpose of a text-based approach is to enable learners to become competent, confident and critical readers, writers and viewers of texts. It involves listening to, reading, viewing and analysing texts to understand how they are produced and what their effects are. Through this critical interaction, learners develop the ability to evaluate texts. The text-based approach also involves producing different kinds of texts for particular purposes and audiences. This approach is informed by an understanding of how texts are constructed. This approach will require quite a lot of modelling, support and scaffolding in the First Additional Language classroom.

The DBE clearly explains the purpose of the approach, how it works and mediation strategies involved, such as modelling and scaffolding. The range of text types and lengths of texts are stipulated in the curriculum as a means of providing guidance for teachers to teach within specified parameters.

Feez and Joyce (1998) present a systematic five-phase teaching model for successful implementation of the text-based approach. Building the context is the opening phase, followed by modelling and deconstruction of the text, joint construction of the text, independent construction of the text, and finally, linking of texts to related texts.

On close examination of the text-based teaching model and the DBE (2011) definition, there are several resemblances regarding execution of the text-based approach. The discernible comparisons are, inter alia, the exploration of how texts work and text features; critical interaction, investigation, reflection on texts; construction and production of different types of 
texts; and scaffolding, modelling and support. This relationship is viewed as an indication that according to curriculum standards, the text-based approach objectives can, to a large extent, be achieved by means of the application of the phases presented in the teaching model. A critical issue that remains to be addressed is that of bringing teachers on board through adequate professional development and capacity building.

Globally, research studies indicate successful implementation of the text-based approach in different disciplines and at different levels of education, including higher education (Marina \& Marmiené, 2006; Mthembu-Funeka, 2009; Nel \& Theron, 2008). Crome and Garfiled (2011), for instance, postulate that the text-based approach is 'an approach that is intrinsically linked to what must be the aim of all philosophy in teaching'. They purport that learners learn through 'repeated engagement with various types of texts'. Miyoun (2007: 37) states that proponents of the approach have suggested that it could be 'more suitable for learners at beginning or intermediate levels of proficiency in second language'. By implication, the text-based approach is suitably prescribed for implementation in the South African context. However, whereas these studies confirm positive application of the text-based approach, no study has been conducted specifically to investigate the implementation of the approach in South African public schools in disadvantaged environments.

\section{CONCEPTUAL FRAMEWORK}

The research was informed by three renowned theories in language teaching and learning, namely, Vygotsky's zone of proximal development (ZPD) (Vygotsky, 1978), Krashen's input hypothesis (Krashen, 1985) and Cambourne's conditions of learning (Canbourne, 1995). The ZPD assures that, through adequate mediation and support by a more knowledgeable person, learners have the potential to use their existing knowledge to learn and assimilate new subject matter, and to move towards independent learning (Chaiklin, 2003). Krashen's input hypothesis advocates that learning takes place through reception of comprehensible input that 'contains structures at our next "stage" - structures that are a bit beyond our current level of competence' (Krashen, 1985: 2). The inclusion of comprehensible input supports the ZPD as it encourages progression from a level of knowledge, represented as ' $i+1$ ', thereby providing input and knowledge that goes slightly beyond what the learners have acquired (Tricomi, 1986). Cambourne (1995) models conditions of learning suitable for a conducive teaching and learning atmosphere, comprising immersion, demonstration, engagement, expectation, responsibility, employment, approximations and response. These conditions set standards that are necessary for encouraging learning and development in a non-threatening environment. Cambourne (1995: 187) states that learners need to be immersed in different types of texts and should receive ample demonstrations of how texts are constructed. The demonstrations will help them to engage meaningfully in learning activities, and when they are confident of having the potential to perform the demonstrations they will 'try to emulate without fear of physical or psychological hurt if their attempts are not fully correct' (Cambourne, 1995: 187). The suggestion is therefore that teachers should, within standard parameters, set high expectations for learners, providing assurance and positive belief systems for successful learning. In the interim, learners should take responsibility for how they learn, using the available time to employ and engage meaningfully with tasks. In this model, it is crucial that learners be given the opportunity to approximate the demonstrations. Teachers ought to accept and understand that mistakes are essential for learning 
to occur and learners should not feel intimidated when they make mistakes in the learning process.

\section{RESEARCH DESIGN AND DATA COLLECTION}

The research pursued the qualitative methodology within the ambit of the interpretivistconstructivist paradigm, focusing mainly on classroom observation and semi-structured interviews. Empirical phenomena were captured on a classroom observation protocol designed to record features that represented text-based teaching. The aspects included curriculum conformity, text types and level-appropriateness, teaching methodology, instructional language, learner engagement and classroom environment. Semi-structured interviews with the teachers were used to corroborate classroom observation and to elicit more information regarding knowledge and understanding of text-based teaching. The interviews were used as a strategy to follow participants' lines of thought and to provide additional information regarding the implementation of the text-based approach (Sharma, 2010).

\section{Participants and sampling procedures}

Purposive non-probability sampling was employed due to availability, convenience and representation of the characteristics the researcher intended to study. The selection of participants was dependent on convenience as well as the researcher's familiarity with the target population and field of study. The participants would therefore provide valuable information regarding the text-based approach, making it possible for the researcher to achieve the desired outcomes of the study.

Three teachers from disadvantaged public primary schools in Tshwane North District, Gauteng, South Africa, voluntarily participated in the study. For ethical reasons, the names of schools and participants were not disclosed. Table 1 displays the biographical details of the participants, depicting their characteristics in terms of gender, age group, teaching experience, number of years teaching English, other subjects taught and qualifications. The participants represented a homogenous target population of teachers, based on the researcher's knowledge of the population and its elements (Babbie, 2010: 193), and for relevance regarding the fulfilment of the purpose of this research. Tshwane North District was instrumental in the selection, focusing on one major criterion, namely, that the schools were implementing the text-based approach in Grade 4 English FAL teaching. Coincidentally, all the selected schools were on the DBE Gauteng Primary Literacy and Mathematics Strategy (GPLMS), a strategy instituted to improve learners' performance in language and mathematics (Gauteng Department of Education, 2014).

The study conformed to ethical requirements, which relate to moral values, professional standards and conduct, to ensure trustworthiness, transparency and confidentiality (Mouton, 2009). The University of Pretoria issued the ethical clearance certificate number HU 14/03/01 and the Gauteng Department of Education granted approval to conduct the research on 28 July 2014. 
Table 1: Participants' biographical information

\begin{tabular}{|l|l|l|l|}
\cline { 2 - 4 } \multicolumn{1}{l|}{ N=3 } & Teacher PA & Teacher PB & Teacher PC \\
\hline School & AA & BB & CC \\
\hline Gender & Male & Female & Male \\
\hline Age group & 40 to 60 & 40 to 60 & 40 to 60 \\
\hline Years of teaching experience & 25 & 20 & 27 \\
\hline Years teaching English & 25 & 18 & 4 \\
\hline Other subjects & Social Sciences & Life Skills & $\begin{array}{l}\text { Sepedi } \\
\text { Social Sciences } \\
\text { Mathematics } \\
\text { Natural Sciences }\end{array}$ \\
\hline Qualifications & & & PTD \\
\hline
\end{tabular}

\section{FINDINGS}

This research is centred on the critical notion that policy is fundamental to effective teaching practice. Therefore, the findings depict the degree to which policy (curriculum) informs actual classroom practice (implementation), including the participants' knowledge and understanding, to achieve curriculum purposes. Classroom observation shed light on actual teaching practice while the interviews revealed the participants' knowledge and understanding of matters that are crucial for the achievement of curriculum goals.

Figure 1 represents the interrelated themes emerging from the actual teaching practice, providing answers to the research question: How is the text-based approach to teaching English implemented in Grade 4 to ensure communicative competence?

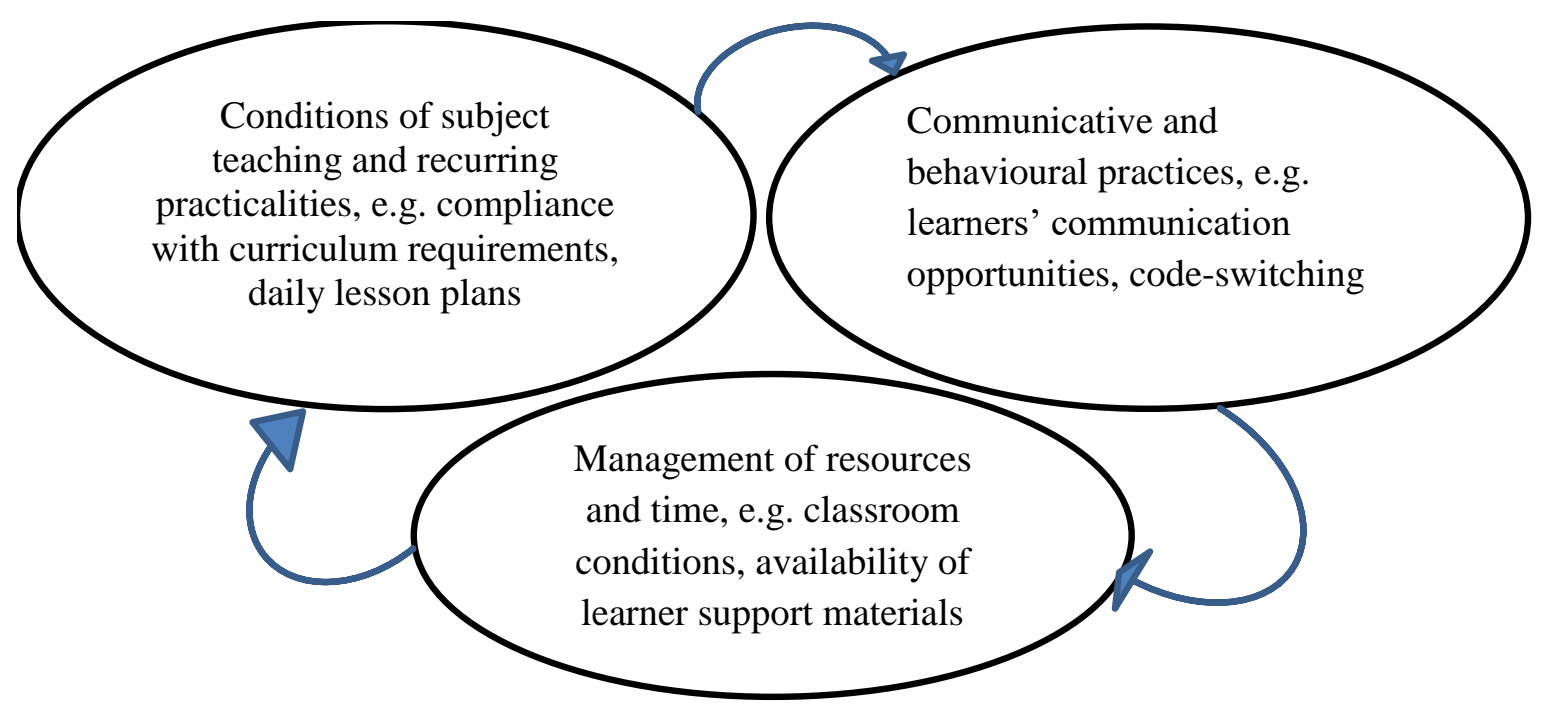

Figure 1

Per Linguam 2017 33(2):22-35

http://dx.doi.org/10.5785/33-2-713 


\section{Teaching practice}

The prescriptive nature of the CAPS was alluded to in the introduction, with reference to the texts to be taught and the timeframes in terms of weeks in each term of the year. The findings showed that prescribed texts for the specified period in the CAPS were used appropriately in a manner that satisfied the application of a text-based approach. As mentioned earlier, the schools were on a departmental language intervention strategy which entrenched teaching based on curriculum stipulations. Teachers used and followed, to the letter, what was referred to as 2014 Term 3 Lesson Plans that contained instructions and structure for each daily lesson. These were used in conjunction with learners' workbooks. The lessons were structured and process-based, with differentiated strategies such as before reading, reading and after reading.

Predominantly, teachers read aloud and learners repeated after them in choral unison. Choral unison manifested itself as a form of drill and repetition that was evidently normal daily exercise and learners seemed au fait with it. Learners' communication was confined to answering lowerorder questions which encouraged simple reproduction of facts - a process that did not require deeper or critical thinking skills (Sardareh \& Saad, 2013) - and non-verbal communication when following the teacher's instructions. What is commonly known as a traditional teacher-centred mode of teaching unfolded and, although the teachers provided comprehensive input, it was restricted to giving instructions and asking questions, accompanied by frequent use of codeswitching.

Educationists assert that conditions of learning, when taken into consideration, feature essential effective learning aspects, for example, a non-threatening classroom climate, acceptable teacherlearner relationship, provision of adequate resources and meaningful learner involvement. The conditions embrace classroom management in a broader sense, which, according to Cambourne (1995: 185), 'enable language to be learnt'. Classroom conditions were acceptable and the teachers exuded positive professional attributes. They were caring and in control, and the classrooms neat and well-organised, with minimal print materials on display.

Except for one, the classrooms had multiple copies of reading books and group readers, and each learner had a workbook. Literally, the classrooms were poorly resourced, since the available materials were provided specifically for the implementation of the language intervention strategy. The CAPS curriculum prescribes a range of learning and teaching support materials, stating that learners should have access to core materials in the form of prescribed textbooks and dictionaries, readers containing stories, drama, poetry, information texts, as well as media materials which include radio and television programmes (DBE, 2011: 19). Additional resources, such as Big Books or enlarged texts and audio visual aids are prescribed, yet none of the CAPSlisted materials were available in the classrooms.

\section{Curriculum knowledge}

This section provides answers to the question: What is the teachers' understanding of the textbased approach? Significant information was uncovered which clarified the participants' knowledge and understanding of curriculum content and delivery. For relevance to this article, a few questions were selected from the 15 presented in the main thesis. 
The teachers' lack of knowledge and understanding of curriculum matters was a grave concern. This shortcoming became evident when, throughout, the participants were uncertain when responding to the questions relating to the curriculum and its implementation. Curriculum knowledge is central to achieving curriculum purposes. It comprises in-depth knowledge and understanding of curriculum stipulations, content and the integrated teaching strategies for achieving desired goals and expectations. It forms a critical base that is congruent with Aristotle's three-tiered framework of knowledge: 'theory (know that), technique (know how to) and moral insight (know why)' (Solomons \& Fataar, 2011: 227).

The text-based approach, as one of the prescribed approaches, is a concept with which teachers implementing the CAPS should be familiar. To the contrary, when asked what their understanding of the text-based approach was, PA, a male teacher from School AA, answered, 'Text-based approach?' Pause. 'Please explain.' ... 'My understanding is that it is not abstract, it is based on a text. The text is used as the foundation.' Showing signs of uncertainty, PB, a female teacher from School BB, said, 'It is when learners are actively involved and taking part in the lesson, expressing themselves freely during the lesson. They are then able to understand things in context.' Of the three, PC was the oldest male teacher, from School CC. He replied, 'Ahem ... text-based approach ... my understanding ... I have to read the text and thereafter explain the words so that they can understand the words and spelling. You must always make them aware of punctuation marks.'

To ensure implementation of the approach in FAL teaching, PA said, 'First, I read and understand the story. Then I prepare well and impart the knowledge to the learners.' PB was confident to say, 'I make use of practical language. When I teach I use pictures and real objects and I encourage learners to use full sentences in their daily activities. I give them lots of examples, trying to explain in the first additional language.' PC explained in this manner, 'I try by putting it in my words; in my language first. Thereafter, I put it in the other language, which is Zulu or Tsonga and thereafter I make it a point that the learners listen to the words and say the words and later they have to write it.' The researcher intervened and asked, 'Do you start by using mother tongue?' 'Yes,' he confirmed, 'let's say it is vocabulary. I'll explain in my language and then if I know it in Zulu then I give it in Zulu and then in Tsonga. But if I am having a problem with that language I ask the learners. At times they know.'

The text-based approach was deemed suitable for achieving the purpose of teaching English FAL, as depicted in these responses. PA said, 'Yes, the text is a foundation for teaching. It is easier to understand the text and to teach language structure and conventions, vocabulary and tense. It is very suitable for understanding.' PB affirmed, 'Yes. It covers the content in language and all the skills ... for example, listening, speaking, reading and writing and language structure and conventions,' and PC concurred, 'Yeah, I think it puts a learner in a situation that he has to think, then after thinking he finds words that he is not familiar with. He has to learn new things every day. And the text also will teach him about something which he hasn't experienced before.'

PA noted that the text-based approach had a disadvantage, because 'learners rely too much on the text; they copy from the text instead of thinking. Their thinking is only based on the text.' Exuding her energetic nature, PB said, 'Unless you are a lazy teacher and if you do not teach according to the set guidelines.' (For clarity, the guidelines refer to the GPLMS scripted lesson instructions.) PC contemplated, 'Yeah, disadvantages I think ... if I do not know the language, if I Per Linguam 2017 33(2):22-35 http://dx.doi.org/10.5785/33-2-713 
do not understand the language and I try to teach the language, it's a disadvantage. (Researcher: 'The language - do you mean English?') 'I have to relate what I am teaching to somewhere to bring together for the understanding of the person I am teaching, and relating sources to understand.'

Asked whether they code-switched when teaching English, PA answered, 'At the beginning of the year I am forced to. To make learners understand because it is their transition from Grade 3. In foundation phase things were different.' PB said, 'Sometimes. I know I am cheating. The GPLMS discourages this. It is wrong, but I am trying to make learners understand since English is their second language. I am forced to. These learners are only in Grade 4 and are not advanced with the language. They start English in Grade ...? I'm not sure. I'll check.' PC confirmed, 'Yeah, at times I do that, eh ... because I think without that they won't understand. It's like one day I was speaking with the Chinese. We were talking in English then he talks with the Chinese language. Then I say you are rebuking me. Learners would not understand certain concepts, at times.'

In spite of the lack of curriculum knowledge, participants raised pertinent issues when interrogated about the purpose for teaching English FAL. According to PA, English is $a$ universal language. Learners must be able to use English because it is also a LoLT.' PB responded, 'English is an international language. Learners must know it so that they can compete with other learners. They must be able to use it at home to express themselves and solve problems. They must use it when they play, for example, when they play with white children. It gives them a sense of belonging.' PC said, 'The reasons for teaching English is to prepare a child for the world when he goes out to work, when he visits other places and people who don't know his or her language. He can use the language and then also in the workplace and also in sports, they use English.'

The issues mentioned with regard to the purpose of teaching English could justly be linked to the CAPS, which maintains that 'learning to use language effectively enables learners to acquire knowledge, to express their identity, feelings and ideas, to interact with others and their world' (DBE, 2011:11). In addition, participants echoed known societal aspirations for learning English and its usage, such as its prominence as an international language, its predominant use at the workplace, its position as a social language and, primarily, its LoLT status in certain South African public schools.

\section{DISCUSSION}

The findings of this research provided significant information regarding implementation of the text-based approach in context of the selected schools. The participants' knowledge and understanding of related curriculum matters were revealed. In this article, the authors clearly articulated their stance pertaining to the development of communicative competence as a critical learning outcome in text-based teaching. Hence, this discussion presents factors that drive the promotion of the development of communicative skills in the teaching and learning process. Furthermore, the discussion addresses issues posed in the questions, with the inclusion of salient matters that were deemed appropriate in answering the research questions. 
Two strong points surfaced. Firstly, the text-based-approach was implemented in the Grade 4 FAL classrooms. Secondly, the teachers were eagerly committed to the execution of policy according to prescribed standards. However, parallel to these solid points were underlying factors that became apparent, relating to teaching practice, curriculum knowledge and the achievement of curriculum goals.

In their enthusiasm to implement policy, the teachers unfailingly focused on completing daily tasks as set out in the pre-scripted lesson plans. In essence, this form of policy implementation defeats the mission of the curriculum in a number of ways. For example, the curriculum envisages a 'high level of proficiency' (DBE, 2011: 13) as an outcome of FAL teaching. However, paying attention to the completion of daily tasks for successful completion of intervention programmes cannot be equated to teaching for its own sake or for the development of the requisite language skills. It must be noted that the GPLMS was intended to improve learner performance, particularly in preparation for learners' performance in the annual national assessments (Gauteng Department of Education, 2014). An additional factor is that this form of implementation is restrictive and could possibly contribute to the lack of essential effective teaching mechanisms, such as teachers' independent creativity, innovation and meeting learners' individual needs. Hence, the limited learner engagement and participation, as revealed, were indicative of an inflexible mode of teaching that lacked crucial prescribed methodological techniques such as scaffolding, modelling and support (DBE, 2011). This limitation confirms the possibility that many practising teachers are unfamiliar with theories which inform best teaching practice.

The findings showed that learners' communication was confined to answering lower-order questions, repetitive drills in choral unison and non-verbal communication when following the teacher's instructions. It was evident that learners were used to the teacher-centred mode of teaching and learning, which inhibited learners' communicative exercise in the FAL. The dominance of teacher talk itself points to neglected learners' communicative output, resulting in poorly developed language skills. Mohr and Morh (2007: 441) confirm that 'teacher talk is often managerial rather than conversational in nature' and that it 'primarily displays questions which expect students to recall information' rather than encouraging learners to practise communication skills in the additional language.

The teachers' lack of knowledge and understanding of curriculum matters was a grave concern. As mentioned earlier, many of the responses were uttered unconvincingly, with the use of professional and educated guesses. Whereas the participants seemed to understand the purpose of teaching English and acclaiming the text-based approach, they displayed inadequate knowledge of theoretical concepts presented in the curriculum, the understanding of the approach and how it was supposed to be practically executed. The lack of knowledge is considered a serious shortcoming in teaching practice and it is detrimental to curriculum management and delivery. Undoubtedly, this form of deficiency contributes to the poor quality of education that prevails in many South African public schools (Hart, 2009; National Education Evaluation and Development Unit, 2012; Spaull, 2013). In this article, we argue that pedagogical content knowledge is critical for curriculum implementation and teaching practice, and that it leads to the achievement of the envisaged goals and beyond. 
Furthermore, there was the issue of code-switching, which the teachers used for various justifiable situational reasons. For example, teachers switched because learners did not understand English and because English was introduced late in Grade 3 or 4. However, according to the teachers, code-switching was not allowed. This issue raised concerns, owing to the fact that code-switching was officially encouraged, if necessary, and it is documented in the CAPS (DBE, 2011: 77, 150). It was evident that, due to limited knowledge of curriculum matters, teachers were misinformed about code-switching. One participant mentioned that codeswitching was wrong and said that it was 'cheating', as it was discouraged in the GPLMS. Had the teachers been familiar with curriculum content, they would have known that code-switching was indeed supported and could be used strategically for meaningful teaching and learning (McCabe, 2013; Vorster, 2008). It should be noted that learners in the selected schools came from different linguistic backgrounds, for instance, Sepedi, Setswana, IsiZulu and Xitsonga, while some were foreign nationals. The diverse linguistic situation posed an additional challenge, as one of the teachers indicated that learners were able to assist when he was not sure of the language.

A major expectation for successful curriculum implementation is the provision of adequate resources. Although various types of texts were prescribed in the CAPS (DBE, 2011), none was available in the classrooms. As indicated in the findings, the materials found in the classrooms were specifically provided for the implementation of the GPLMS. Research shows that a variety of good books and quality, well-illustrated reading materials encourage learners to love reading and help in the improvement of literacy and academic achievement (Moodie, 2010; Plunkett, Aslanian \& Hastings, 2005). Access to a variety of texts conforms to one of the conditions of learning - immersion - which encourages that learners should be immersed in appropriate texts of various types for improved performance (Cambourne, 1995; Williams, Coles \& Wavell, 2002). What remains is the difficulty to fathom what resources the classrooms would have had if not for the departmental intervention strategy.

\section{CONCLUSION}

The purpose of this article was to give an account of research conducted to establish the contribution of a text-based approach in FAL teaching for the development of learners' communicative competence. It drew attention to the fact that policy should not only inform, but also support, teaching practice. Although the research was not intended to evaluate the GPLMS language intervention programme, it revealed that the text-based approach was executed, by chance, through rigid implementation of the programme. This was achieved by means of scripted lessons which teachers followed rigidly, thereby encouraging a predominantly teacher-centred mode of teaching. Whereas the text-based approach was in place, teachers had limited knowledge and little was accomplished in terms of the achievement of learners' communicative competence, as it was mentioned that learners could merely communicate issues or answer questions based on familiar texts. Concerning learning support materials, learners were exposed to a minimal range of texts.

The authors purport that effective teaching, for the achievement of curriculum obligations, is dependent upon reasonable levels of pedagogical content knowledge and provision of adequate resources. Low levels and inadequacies such as those revealed in this article incorporate considerable pedagogical implications that contribute to recurring poor learner performance, as

Per Linguam 2017 33(2):22-35

http://dx.doi.org/10.5785/33-2-713 
indicated earlier on. These include, among others, lack of creativity, originality, flexibility and the pleasure of teaching, and have the potential to affect the teacher's morale. The researcher recommends that the teachers' willingness to observe and follow instructions should be valued as a strong point on which to build continuous teacher training and development. A systematic, directly hands-on teacher training model that includes theory and practice, coupled with practical classroom demonstrations, is of critical necessity. O'Connor and Geiger (2009) confirm that teachers 'wanted to observe practical demonstrations on how to implement the strategies they had learnt, preferably with their own learners'. The formulation of practicable and enabling teaching policies is of utmost importance. Essentially, policies should be unpacked and broken down for meaningful and successful implementation.

\section{REFERENCES}

AYLIFF, D. 2010. 'Why can't Johnny write? He sounds okay!' Attending to form in English second language teaching. Perspectives in Education, 28(2):1-8.

BABBIE, E. 2010. The practice of social research. Belmont, CA: Wadsworth.

CAMBOURNE, B. 1995. Toward an educationally relevant theory of literacy learning: twenty years of inquiry. The Reading Teacher, 49(3):182-190.

CHAIKLIN, S. 2003. The zone of proximal development in Vygotsky's analysis of learning and instruction. In Kozulin, A, B Gindis, VS Ageyev \& MS Miller (Eds), Vygotsky's educational theory in cultural context. Cambridge: Cambridge University Press.

CROME, K \& M GARFIELD. 2011. Text-based teaching and learning in philosophy. Available from http://www.basr.ac.uk/trsresources/.../discourse/DiscourseArticles/161 [Accessed: 15 September 2014].

DEPARTMENT OF BASIC EDUCATION. 2011. Curriculum and assessment policy statement (CAPS), intermediate phase, first additional language. Pretoria: Department of Basic Education.

FEEZ, S \& H JOYCE. 1998. Text-based syllabus design. Sydney: National Centre for English Language Teaching and Research, Macquarie University.

GAUTENG DEPARTMENT OF EDUCATION. 2014. Gauteng primary literacy and mathematics strategy (GPLMS): term 3 lesson plan, Grade 4 English first additional language. Johannesburg: Gauteng Department of Education.

HART, M. 2009. Reading to learn in South African schools. Paper presented at the Reading to Learn in Western NSW Region Conference.

HOADLEY, U. 2012. What do we know about teaching and learning in South African primary schools? Education as Change, 16(2):187-202.

HYMES, DH. 1966. On communicative competence. Paper revised from one presented at the Research Planning Conference on language development among disadvantaged children. Department of Psychology and Guidance. Ferkauf Graduate School, Yeshiva University.

HYMES, DH. 1972. On communicative competence. In Pride, JB \& J Holmes (Eds), Sociolinguistics: selected readings. Harmondsworth: Penguin. 269-293.

JORDAAN, H. 2011. Language teaching is no panacea: a theoretical perspective and critical evaluation of language in education within the South African context. South African Journal of Communication Disorders, 58(2):1-13.

KILLEN, R. 2015. Teaching strategies for quality teaching and learning (2nd ed.). Cape Town: Juta.

KRASHEN, S. 1985. The input hypothesis: issues and implication. London: Longman.

LEE, HLJ. 2010. Code switching in the teaching of English as a second language to secondary school students. Malaysian Journal of ELT Research, 6:1-45.

McCABE, R. 2013. Scaffolded code-switching: a resource for achieving academic literacy? Journal for Language Teaching, 47(2):159-194.

Per Linguam 2017 33(2):22-35

http://dx.doi.org/10.5785/33-2-713 
MARINA, V \& A MARMIENE். 2006. Text-based language teaching and the analysis of tasks presented in English course book for students of information technology and computing. Filologija, Edukologija, 14(2):99-105.

MIYOUN, SK. 2007. Genre-based approach to teaching writing. Teaching English as Second Language, 6:33-39. Available from http://www.sagepub.com/combsstudy [Accessed: 12 May 2013].

MOHR, KAJ \& ES MOHR. 2007. Extending English-language learners' classroom interactions using the response protocol. The Reading Teacher, 60:440-450.

MOODIE, A. 2010. South Africa: Row over research into school books. University World News, (61).

MOUTON, N, GP LOUW \& G STRYDOM. 2013. Critical challenges of the South African school system. International Business and Economics Research Journal, 12(1):31-44.

MTHEMBU-FUNEKA, WNZ. 2009. Genre-based approach to IsiZulu home language education as a means to successful English first additional language education. Unpublished $\mathrm{PhD}$ thesis. University of Zululand, Kwadlangezwa.

MULLIS, IVS, MO MARTIN, P FOY \& KT DRUCKER. 2012. PIRLS 2011 international results in reading. USA: TIMSS and PIRLS International Study Centre.

NATIONAL EDUCATION EVALUATION AND DEVELOPMENT UNIT. 2012. National Report 2012. The state of literacy teaching and learning in the foundation phase. Pretoria: NEEDU.

NEL, M \& L THERON. 2008. Critique of a language enrichment programme for Grade 4 ESL learners with limited English proficiency: a pilot study. South African Journal of Education, 28:203-219.

O'CONNOR, J \& M GEIGER. 2009. Challenges facing primary school educators of English second (or other) language learners in the Western Cape. South African Journal of Education, 29:253-269.

PLUNKETT, SW, M ASLANIAN \& R HASTINGS. 2005. The BookEnds program: an evaluation study, report no. 2. West Hills, CA: BookEnds.

PRETORIUS, EJ. 2012. Butterfly effects in reading? The relationship between decoding and comprehension in Grade 6 high poverty schools. South African Association for Language Teaching, 46(2):74-95.

RICHARDS, JC. 2006. Communicative language teaching today. Cambridge: Cambridge University Press.

SARDAREH, SA \& MRM SAAD. 2013. Malaysian primary school ESL teachers' questions during assessment for learning. English Language Teaching, 6(8):1-9.

SCHLEBUSCH, G \& T MOTSAMAI. 2004. Outcomes-based education in the English second language classroom in South Africa. The Qualitative Report, 9(1):35-48.

SELIGMANN, J. 2011. Academic literacy for education students. Southern Africa: Oxford University Press.

SHARMA, S. 2010. Qualitative approaches in mathematics education research: challenges and possible solutions. Education Journal, 2(2):50-57.

SHULMAN, LS. 1986. Those who understand: knowledge growth in teaching. Education Research, 15(2):4-14.

SOLOMONS, I \& A FATAAR. 2011. A conceptual exploration of values education in the context of schooling in South Africa. South African Journal of Education, 31:224-232.

SPAULL, N. 2013. South Africa's education crisis: the quality of education in South Africa 1994-2011. Johannesburg: Centre for Development and Enterprise.

TAYLOR, N. 2008. What's wrong with South African schools? What's working in school development. Available from http://www.jet.org.za [Accessed: 10 May 2015].

TRICOMI, ET. 1986. Krashen's second-language acquisition theory and the teaching of edited American English. Journal of Basic Writing, 5(2):59-69.

VAN SCHALKWYK, SC. 2008. Acquiring academic literacy: a case of first-year extended degree programme students at Stellenbosch University. Stellenbosch University, Stellenbosch.

Per Linguam 2017 33(2):22-35

http://dx.doi.org/10.5785/33-2-713 
VAN STADEN, A. 2011. Put reading first: positive effects of direct instruction and scaffolding for ESL learners struggling with reading. Perspectives in Education, 29(4):10-21.

VORSTER, H. 2008. Investigating a scaffold to code-switching as strategy in multilingual classrooms. Pythagoras, 67:33-41.

VYGOTSKY, LS. 1978. Interaction between learning and development. In Cole, M, V John-Steiner, S Scriber \& E Souberman (Eds), Mind and society: the development of higher psychological processes. Cambridge, MA: The Harvard University Press.

WILLIAMS, D, L COLES \& C WAVELL. 2002. Impact of school library services on achievement and learning in primary schools: critical literature review of the impact of school library provision on achievement and learning in primary level students. London: Department for Education and Skills and Resource, The Council for Museums, Archives and Libraries.

\section{BIOGRAPHICAL NOTES}

Ntombi Mohlabi-Tlaka holds a NRF supported $\mathrm{PhD}$ in Humanities Education (UP). Her thesis, The contribution of a text-based approach to English education for communicative competence, interrogated curriculum implementation, bringing critical matters that affect EFAL teaching to the fore. The thesis received a Research Indaba 2016 award sponsored by Bookmark for exceptional completed PhD. She is currently a lecturer at Unisa in the Department of English Studies.

Lizette J. de Jager holds a PhD in Curriculum and Instructional Design and Development (UP). In her thesis, Misunderstanding in second language instructional communication, she explored the nature and consequences of misunderstandings identified in authentic lesson presentations of pre-service teachers who used English L2 as the medium of instruction, for which she received the award for best scholarly engagement at PhD level at the Research Indaba of the Faculty of Education (2012). She is currently a lecturer in English Literature and Grammar, and English Methodology in the Department of Humanities Education at the University of Pretoria.

Alta Engelbrecht holds a $\mathrm{PhD}$ (UP) in curriculum studies and is a lecturer in the Faculty of Education at the University of Pretoria. She mainly works in the focus area of power, reform, change and continuity in education. She has published extensively in the fields of stereotyping and textbooks. She currently teaches Afrikaans methodology to undergraduate students. Four $\mathrm{PhD}$ and two M.Ed. students have graduated under her supervision. 